\title{
Effect of Social Media Marketing on The Conversion Rate of Deposit Money Banks in Nigeria
}

\author{
Newman C. Enyioko *) \\ Gabriel A. Okwandu **)
}

\begin{abstract}
The study examined the effect of social media marketing on the conversion rate of deposit money banks in Nigeria. Blog, Facebook, Twitter, and LinkedIn were used as the dimensions of social media marketing. The study revealed a gap from the literature that social media marketing and organizational efficiency of banks in Nigeria has not been extebsively studied in Nigeria. The study used the conversion rate as a dependent variable. The study adopted descriptive and inferential statistical tools to analyze the data and test the hypotheses. A questionnaire was used to elicit information from the respondents. The population of the study consisted of all the 22 banks approved by CBN. The study sampled 159 respondents from 22 banks in Nigeria and validly used 133 respondents representing $83.65 \%$ response rate for data analysis. The study found that banks use a blog, Facebook, Twitter, and LinkedIn to conduct their marketing activities for brand promotion and persuasion of customers to patronize them. The study revealed that Blog has a positive but insignificant effect on conversion rate. The study discovered that Facebook has a positive and significant effect on conversion rate. The study revealed that Twitter has a positive and significant effect on conversion rate. The study found that LinkedIn has a positive and insignificant effect on conversion rate. The study concludes that as banks use blogs, Facebook, Twitter, and LinkedIn to create awareness about their products and services on the internet. The study recommends that bank managers should use Blog, Facebook, Twitter, and LinkedIn by encouraging all the bank staff to participate in social media marketing which in turn covers more ground for the enhancement of conversion rate leading to the conversion rate of banks.
\end{abstract}

Keywords: Social Media Marketing; Blog; Facebook; Twitter; LinkedIn; Conversion Rate; Marketing Performance

\section{INTRODUCTION}

\subsection{Research Background}

Social media marketing is defined by Elena (2016) as a new era- revolutionizing - tool that allows communication between individuals, companies and different groups from all around the world to share and interactively exchanges information and ideas to attract customers to patronize their companies. Social media marketing platforms such as Facebook, Instagram, Twitter, LinkedIn, and Blog have offered the opportunity for clients to discuss their online programmes, projects, reviews, recommendations and agree or disagree regarding different aspects of products or customer services. With the opportunities offered, social media marketing has had a major impact on how companies communicate with their distributors and customers, thus the traditional marketing may not have all these elements to cater for the customers' needs and wants (Rapp, Beitelspacher, Grewal, \& Hughes, 2013; Kumar \& Salo, 2018).

Twitter, LinkedIn, Blog, Facebook, Google+ and various other web traffic have hundreds of millions of active users engaging in marketing activities through their platforms. Social media have importance for general web clients as well as businesses. Social media allude to the methods for 
communications among individuals in which they make, share, as well as trade data and thoughts in virtual networks and systems (Järvinen \& Karjaluoto, 2015).

Several studies have shown that banks' use of social media can lead to great advantages, such as, strengthening relationship with customers and creating awareness. However, there are still challenges that decrease the incitement to adopt social media as a marketing strategy. Fisher (2009) and McCann \& Barlow (2015), all agree that the major challenge is the lack of well-developed key performance indicators to measure the effects of the activities.

\subsection{Research Problem}

a) To what extent does the blog affect conversion rate of banks?

b) To what extent does Facebook affect conversion rate of banks?

c) To what extent does Twitter affect conversion rate of banks?

d) To what extent does LinkedIn affect conversion rate of banks?

\subsection{Research Purpose}

This study aims to determine the extent to which blog affects conversion rate of banks, to investigate the extent to which Facebook affects conversion rate of banks, to find out the extent to which Twitter affects conversion rate of banks and to explore the extent to which LinkedIn affects conversion rate of banks.

\section{THEORETICAL FRAMEWORK AND HYPOTHESES DEVELOPMENT}

\subsection{Social Penetration Theory}

The social penetration theory focuses on how human exchange results in relationships (Altman \& Taylor, 1973). It focuses more on the individual and small group levels while the social exchange theory explains behavior at aggregated and or organizational levels. Social exchange theory postulates that people form close relationships through self-disclosure. It notes that one must disclose himself by continuously exposing his inner self through such information as gender, clothing preferences, ethnicity and slowly the relationship progress to the level of sharing inner feelings and goals, followed by sharing of one's feelings, ambitions, and belief (Altman, Vinsel, \& Brown, 1981). In social media marketing, different layers of information can be separated by marketers through designing social networks. There might also be ways to determine the levels of relationships from the mode and frequencies of communication, which could be tracked online easily through web traffic. Gaudin (2010) notes that a recent privacy lawsuit against Facebook highlighted the importance following the laid down rules of social penetration.

\subsection{Social Media Marketing}

There is no precise or inclusive definition of social media marketing because of the dynamic nature of social media marketing today as different definitions of social media marketing have been developed by different scholars. Nevertheless, Social media marketing is a new observable fact of traditional marketing which allows marketers to speed up their communication with their customers. Social media marketing is also seen by (Ryan, 2014) as an interaction between the marketers and their consumers through a two-sided digital platform. Social media marketing also pertains to the use of technology-based marketing tools to promote fast and efficient communication and delivery to product users. It is well known that social media marketing has technology as its bottom-line to enables easy communication with the customers, as well as facilitates 'the interaction' phase of marketing. For Nwokah \& Aeenee (2017), social media 
marketing is the use of internet marketing channels like Blogs, Twitter, mobile phones, etc., to reach customer satisfaction.

Social media marketing is carried out on social media which is seen as internet and mobilebased social networking platform built on the foundations of webs that allow users to exchange information, interact, and socialize with others, as well as share opinions and content. It also deals with the building of networks and encouragement of user participation, engagement and content creation (Chaffey \& Smith, 2013; Charlesworth, 2014). Currently, social media constitutes as one of the most significant toolkits obtainable in digital marketing communications. Bax, Meyer, \& Wilkins (2013) state that today, many businesses have made social media central to their marketing activities. Social media tools are used by businesses to achieve marketing objectives, communicate their new products, present their offers and sales, building customer loyalty and providing real-time customer service.

Some major benefits of social media marketing are that it helps the marketers to measure and know the level the customers perceive and experience brand equity (Kanovska \& Tomaskova, 2012), help to continuously take on new customers while keeping the existing ones (Hoban \& Bucklin, 2015). Also, Hoban \& Bucklin (2015) note that the effectiveness of social media marketing is mainly determined by communication occurrence and communication content. It also reduces the roles of agents drastically since organizations can market directly to the consumers' social media.

In their investigation of the mix of new media with more traditional techniques, Batra \& Keller (2016) called attention to that incorporation of advertising interchanges which is critical for effective promotion exercises in the light of mechanical advances of social media, very moving media designs, and holding firm on a customer who has separated consideration. Further, Batra \& Keller (2016) opine that "social media marketing, specifically, offers gigantic potential benefits through their more noteworthy adaptability and accuracy, yet they likewise make more prominent business challenges". Online life advertising increases customer expansion, creates faithful fans, gives commercial center knowledge, and produces/ showcases leads.

Social media are utilized by B2B companies in different ways such as monitoring and listening platform of what the customers are commenting about the company's products and services, provision of support to customers through answering questions and providing information. Ashley \& Tuten (2015) state that social media is used to execute specifically targeted campaigns and engage customers on social media platforms, with the aim of achieving overall business and marketing objectives.

\subsection{Social Media Marketing and Banking Sector in Nigeria}

Today's banking organizations should expand their distribution channels via mobile, internet, and social media networks. Applications as web-based communication channels have continued to spread mass information to customers. For technological disruptions and increased product complexity, employees' relationships with customers have considerably declined, affecting customer perceptions and attitudes related to their bank. Banks could alleviate customer abrasion and dormancy by creating alternative distribution channels whenever personal interactions are relevant. Also, banks should get their customers involved in their marketing campaigns to improve the brand and achieve competitive advantages. Leveraging the human touch has proved to be a vital means of improving overall banking experience (Dedu \& Niţescu, 2014). 


\subsection{Conversion Rate}

Most often, the conversion rate is utilized as a key performance index (KPI) to appraise the effectiveness and efficiency of e-commerce sites. Naturally, all site managers and owners want to know, "how their conversion rates compare?" (McCann \& Barlow, 2015). The conversion rate is used in this work to measure the efficiency of the surveyed banks. Ling-yee (2011) says that when benchmarking conversion rate, the belief is that its importance is explained to marketing managers so that they could go beyond headline conversion rates to segment conversion by different types of visitors on the Internet. Mehmet \& Clarke (2016) have indicated in their study that the conversion rate should be used to measure the performance of a marketing organization that is engaged in both B2B and B2C marketing activities. They maintain that conversion rate should be calculated thus: Conversion Rate $=$ Total Number of Sales $/$ Number of Leads x 100.

Elena (2016) says that conversion rate strategy is a rational continuation of the connection strategy, as a social media marketing organization continues its practical and receptive communication efforts aimed toward the target audience. In social brand sites, a social media marketing organization seek to utilize quality, relevance, high frequency and response rate of conversations as key strategic factors to gain trust and earn credibility. Järvinen \& Karjaluoto (2015) argue that trust and credibility is a factor of the ability of the brand to accurately and timely response to questions/ inquiries, as well as swap information in a meaningful way.

Consequently, affective trust is based on a shared emotional relationship. Given what trust is to social media, the researcher sought and determined the extent to which trust mediated between social media marketing and conversion rate of banks. The understanding gotten from the review of relevant literature in this study has provided the footing for the operationalization of the conceptual framework of social media marketing and conversion rate of banks moderated by a trust.

\subsection{Blog and Conversion Rate}

Blog marketing has been studied over the last 10-15 years because of its tremendous potential for global business enhancement (Guay, 2015). Much literature exists, for example, in the usage of Web 2.0 and blog marketing platforms in the electronic word of mouth advertising and blog marketing (Halim, 2010). Halim (2010), as well as Murdough (2009), have further studied the use of blog marketing instruments or platforms for global buying and selling activities. The relationship between blog marketing and conversion rate have been discussed and debated in trade publications, corporate and consumer blogs, and a host of professional publications over the last ten years (Murdough, 2009). From this body of work (and much more like it), blog marketing and conversion rate have been viewed as a vital requirement for authenticating the success of social media marketing and management programmes.

\subsection{Facebook and Conversion Rate}

The idea of social marketing has enhanced the significance of marketing by investigating the connections among Facebook customers (Morgan, 2014). Customers have either utilized Facebook to get to a brand or social network or have participated in a network where they can generally check for deals, discharges and sales leads that pertain to them.

Agostino \& Sidorova (2016), contend that digital customers have a feeling of proprietorship among the social media networks, and they at times deny organizations to attack their own particular space simply for the expansion in conversion rate. Without a doubt, Lilien (2016) posits that customers esteem security and dread long-range informal communication destinations which affect chosen companions through conversion rate. Then again, Kumar \& Salo (2018) in their examination revealed that the people who partake in long-range casual correspondence are more 
genuine brave individuals than the people who just all over appreciate individual to individual correspondence to assemble conversion rates, deriving that individuals thought about the insurance concerns and approved of the related threats.

\subsection{Twitter and Conversion Rate}

Social media offers businesses a great platform for improving their brand awareness, boosting their engagement, and getting more traffic, among other benefits. But some of the more overlooked uses of Twitter for marketing are Traffic, lead nurturing and boosting of conversion rates. Twitter, in the experience of Agnihotri, Dingus, $\mathrm{Hu}$, \& Krush (2016), is one of the best platforms for reaching conversion rate. Elliot (2015) insists that before starting to optimize Twitter for conversions, they need to be tracked. Appreciatively, Elliot (2015) elucidates thatTwitter makes this easier with the 'conversion tracking' tool. Sen (2015) pieces of advice that setting conversion rate up involves going to the Twitter marketing account, clicking on tools at the top of the dashboard, and then selecting 'conversion tracking. The marketer will need to add a website tag to the site for tracking, much like a Google Analytics tag. Once that is on the site and tied to the Twitter account, Twitter will start to track conversions done through its platform. Twitter also lets marketers create conversion groups to track different portions of the sales funnel.

\subsection{Linkedin and Conversion Rate}

The one-stop shop for everything a sophisticated marketer needs to know about getting the most value from LinkedIn for themselves and their company is the determination of the conversion rate. Basak \& Calisir (2014) assert that LinkedIn is not an instruction manual, but more of a strategic guide full of interviews and tips from marketing thought leaders combined with expert insights from the LinkedIn marketing solutions' team on how to market to who matters. Conklin (2015) argues that LinkedIn is getting ready to take marketing to the next level and discovering the vast opportunities that await the organization. Also, Florenthal (2015) reveals that the LinkedIn marketing platforms increase awareness, engage the audience, generate quality leads, and ultimately drive revenue with products that impact every stage of the conversion rate funnel.

This study evaluated the effect of social media marketing strategies on the conversion rate of deposit money banks in Nigeria. In carrying out the study, four dimensions of social media marketing strategies (independent variables or predictor variables) namely; Blog, Facebook, Twitter, and LinkedIn were examined. These dimensions were adopted in line with the works of Agostino \& Sidorova (2016); Nwokah \& Gladson-Nwokah (2015); Nwokah \& Irimagha (2017) and Cavazza (2018). Also, the conversion rate of banks served as the key dependent or criterion variable under which a measure of conversion rate was appraised. The imperative of the usage of these elements to measure conversion rate of banks has become obvious as could be seen from the conceptual framework of the Study- "social media marketing and conversion rate of deposit money banks."

$\mathrm{H}_{1}$ : Blog has a significant effect on the conversion rate of banks

$\mathrm{H}_{2}$ : Facebook has a significant effect on the conversion rate of banks.

$\mathrm{H}_{3}$ : Twitter has a significant effect on the conversion rate of banks.

$\mathrm{H}_{4}$ : LinkedIn has a significant effect on the conversion rate of banks.

\section{RESEARCH METHOD}

\subsection{Research Design}

The research design that was adopted for this study is a survey approach. This method emphasizes quantitative analysis whereby data is collected through questionnaire, interviews, or 
from existing documents. Based on the information from CBN, Statistical Bulletin, 2017, there are 22 deposit money banks in Nigeria. Regression analysis was used to test the extent of the effect of individual and collective variable(s) on the other. Also, regression analysis was used to test the hypotheses formulated in the study. All these analyses were computed through the use of statistical package for social sciences (SPSS) IBM SPSS Statistics 22 version. The model of this study is as below:

$\mathrm{Y}=\mathrm{b}_{\mathrm{o}}+\mathrm{b}_{1} \mathrm{x}_{1}+\mathrm{b}_{2} \mathrm{x}_{2}+\mathrm{b}_{3} \mathrm{x}_{3}+\mathrm{b}_{4} \mathrm{x}_{4}+\mathrm{e}$------------ $\left\{\right.$ for testing $\left.\mathrm{H}_{1}, \mathrm{H}_{2}, \mathrm{H}_{3}, \mathrm{H}_{4}\right\}$

$\mathrm{CR}=\mathrm{f}(\mathrm{B}, \mathrm{F}, \mathrm{T}, \mathrm{L})$

Where $\mathrm{CR}=$ Conversion Rate $, \mathrm{B}=\mathrm{B} \log , \mathrm{F}=$ Facebook, $\mathrm{T}=$ Twitter, $\mathrm{L}=$ LinkedIn

Table 1 Research Questionnaire

\begin{tabular}{|c|c|}
\hline Variable & Questionnaire \\
\hline \multirow[t]{3}{*}{ Blog } & To what extent does your bank use blog to conduct marketing activities? \\
\hline & To what extent are staff in your bank very skillful in blog marketing? \\
\hline & To what extent does your bank introduce any product or service in the blog? \\
\hline \multirow[t]{3}{*}{ Facebook } & $\begin{array}{l}\text { To what extent does passing marketing information on Facebook lead to the } \\
\text { achievement of the expected marketing results in your bank? }\end{array}$ \\
\hline & $\begin{array}{l}\text { To what extent does your bank give rooms for staff to suggest new ways or } \\
\text { approach for meeting customers satisfactorily on Facebook? }\end{array}$ \\
\hline & $\begin{array}{l}\text { To what extent does the attraction of customers in Facebook become } \\
\text { everybody's business in your bank? }\end{array}$ \\
\hline \multirow[t]{3}{*}{ Twitter } & $\begin{array}{l}\text { To what extent does the quality of interaction between your staff and } \\
\text { customers affect brands in Twitter that directly influence purchase decision? }\end{array}$ \\
\hline & $\begin{array}{l}\text { To what extent are there opportunities to develop the staff on the use of Twitter } \\
\text { to attract customers to your bank? }\end{array}$ \\
\hline & $\begin{array}{l}\text { To what extent do you bank provide staff with Twitter-based facilities to } \\
\text { encourage marketing activities? }\end{array}$ \\
\hline \multirow[t]{3}{*}{ Linkedin } & $\begin{array}{l}\text { To what extent does your bank provide LinkedIn facilities for engaging in } \\
\text { marketing activities that satisfy your customers? }\end{array}$ \\
\hline & $\begin{array}{l}\text { To what extent does your bank offer LinkedIn facilities for on line marketing } \\
\text { activities that give profits to your organization? }\end{array}$ \\
\hline & $\begin{array}{l}\text { To what extent does your bank recognize that LinkedIn provides a customer } \\
\text { with numerous product/service options? }\end{array}$ \\
\hline \multirow[t]{3}{*}{$\begin{array}{l}\text { Conversion } \\
\text { Rate }\end{array}$} & $\begin{array}{l}\text { To what extent does social media marketing boost rate conversion of your } \\
\text { bank? }\end{array}$ \\
\hline & $\begin{array}{l}\text { To what extent are you involved in important marketing activities that improve } \\
\text { the conversion rate of your bank? }\end{array}$ \\
\hline & $\begin{array}{l}\text { To what extent is conversion rate often used as a key performance index (KPI) } \\
\text { to review the effectiveness and efficiency in your bank? }\end{array}$ \\
\hline
\end{tabular}

Source: Survey Data, 2019 


\subsection{Population and Sample}

Therefore, the population of the study is 22 deposit money banks in Nigeria as at 2017 with the senior staff strength of 270 staff (NBS \& CBN Statistical Bulletins, 2017). Therefore, the specific population of the study based on the senior staff strength is 270 . Relying on Krejcie \& Morgan (1970) sample size determination/measurement, the study selected 159 respondents. Copies of the questionnaire were retrieved through established email contacts of the banks by the help of Monkey Survey. A total number of 159 copies of the questionnaire were distributed to the respondents from 22 deposit money banks in Nigeria. A total of 139 copies of the questionnaire were retrieved from them. After editing the retrieved copies of the questionnaire, the copies found useful were 133. The 133 ( $83.65 \%$ response rate) copies of the questionnaire were considered as valid and suitable for data analysis in this study. The sampling technique used in this study was the simple random technique. The sample elements of the study were drawn from the Branch Managers/Accountants, Operations Managers/Supervisors, Customer Service Officers, E-Marketing Managers/Officers and Business Development Manager.

\subsection{Research Framework}

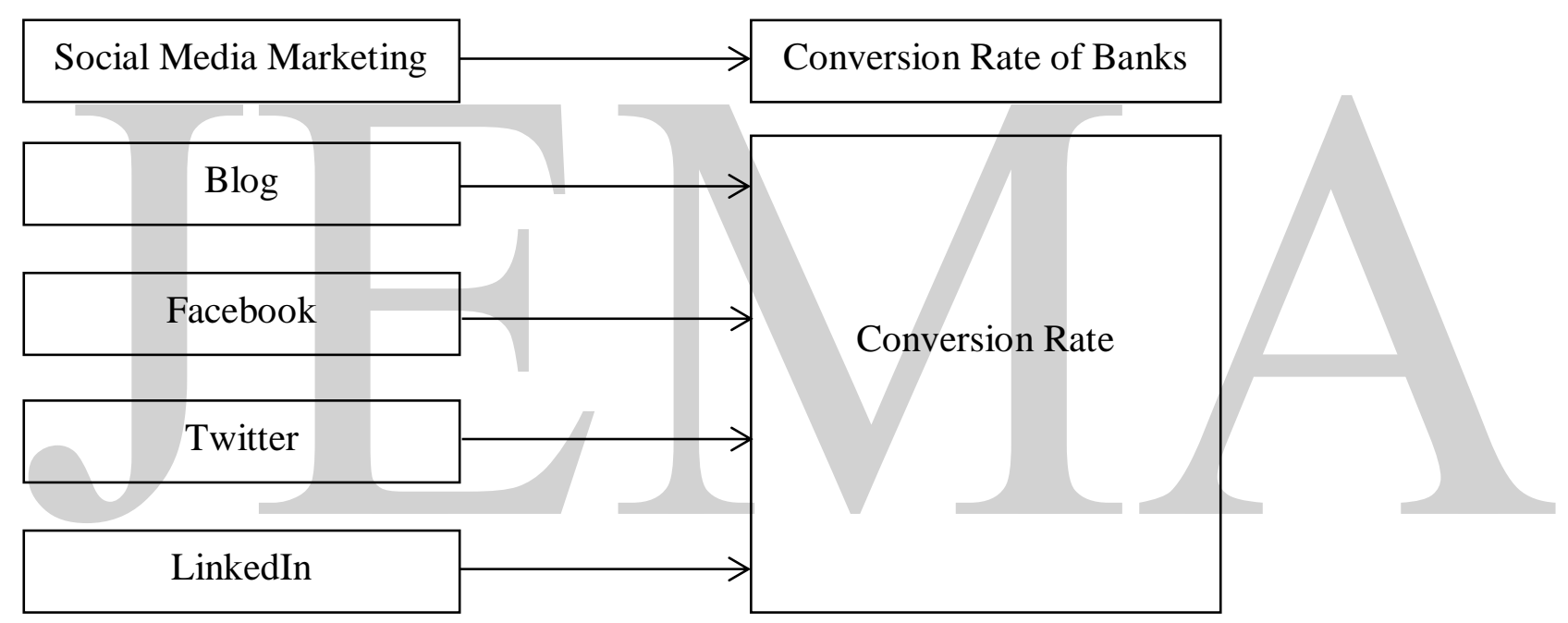

Picture 1 Conceptual Framework of The Effect of Social Media Marketing on Conversion Rate of Deposit Money Banks in Nigeria

\section{RESEARCH RESULT AND ANALYSIS}

\subsection{Descriptive Analysis}

\subsubsection{Blog as a Dimension of Social Media Marketing}

Table 2 gives the detailed analysis on how to blog as a dimension of social media marketing has been examined to determine its effect on organizational efficiency of banks and to show its descriptive statistical outcome based on the questions deposed. Table 2 shows that five question items represent a dimension in the 5-point scale. The data revealed that with the mean and standard deviation scores of $3.9474 \pm 1.0023$, the respondents agreed that to a large extent blog offers veritable opportunities to optimize social media marketing efficiency (conversion rate, web traffic, and customer engagement) in banks. This is followed by the mean and standard deviation scores of $3.8496 \pm 1.0480$, implying that to a large extent banks use the blog to conduct their marketing activities and this elicits organizational efficiency of banks. The data also revealed that to a large extent banks introduce any product or service in their blog; the mean and standard deviation scores 
of $3.8271 \pm 1.0262$ confirm statistically the respondents' agreement that bank introduces any product or service in the blog. With the mean and standard deviation scores of $3.7744 \pm 0.91797$ the respondents indicated that to a large extent banks' staff are very skillful in blog marketing and that helps the banks to be efficient in their operations. Finally, the data in Table 2 revealed that with the mean and standard deviation scores of 3.6992 \pm 1.1077 , the respondents agreed that to large extent customers talk good about banks' willingness to use the best blog instruments/facilities for marketing activities.

Table 2 Blog as a Dimension of Social Media Marketing

\begin{tabular}{|l|l|c|c|}
\hline & \multicolumn{1}{|c|}{ Question Items } & Mean & Standard Deviation \\
\hline 1 & $\begin{array}{l}\text { To what extent does your bank use blog to conduct } \\
\text { marketing activities? }\end{array}$ & 3.8496 & 1.0480 \\
\hline 2 & $\begin{array}{l}\text { To what extent are staff in your bank very skillful in } \\
\text { blog marketing? }\end{array}$ & 3.7744 & 0.91797 \\
\hline 3 & $\begin{array}{l}\text { To what extent does blog offer veritable opportunities } \\
\text { to optimize social media marketing efficiency } \\
\text { (conversion rate, web traffic, and customer } \\
\text { engagement) in your bank? }\end{array}$ & 1.9023 \\
\hline 4 & $\begin{array}{l}\text { To what extent does your bank introduce any product or } \\
\text { service in the blog? 3.8271 }\end{array}$ & 1.0262 \\
\hline 5 & $\begin{array}{l}\text { To what extent do customers talk good about your } \\
\text { bank's willingness to use the best blog } \\
\text { instruments/facilities for marketing activities? }\end{array}$ & 3.6992 & 1.1077 \\
\hline
\end{tabular}

Source: Survey Data, 2019, and IBM SPSS Statistics 22 Window Output

Keys: VLGE = very large extent, $\mathrm{LGE}=$ large extent, $\mathrm{MDE}=$ moderate extent, $\mathrm{LWE}=$ low extent,

VLWE: very low extent, S.D: standard deviation.

\subsubsection{Facebook as a Dimension of Social Media Marketing}

As shown in Table 3 above, the responses of the respondents have indicated the mean and standard deviation scores of $3.7820 \pm 1.06841$, showing that the respondents collectively agreed that to a large extent bank give rooms for staff to suggest new ways or approach for giving potential and actual customers satisfactory information on Facebook. Also, with the mean and standard deviation scores of 3.6992 \pm 1.10086 , it is quite obvious that the respondents indicated on the aggregate that to a large extent passing marketing information on Facebook leads to the achievement of the expected marketing results in banks. As to the extent to which the attraction of customers on Facebook becomes everybody's business in banks, the mean and standard deviation scores of 3.6316 \pm 1.06936 indicate aggregately that attraction of customers on Facebook becomes everybody's business in banks. The data additionally revealed that to a large extent Facebook offers veritable opportunities to optimize social media marketing efficiency (conversion rate, web traffic, and customer engagement) in banks; this is shown by mean and standard deviation scores of 3.5188 \pm 1.16516 . Finally, the mean and standard deviation scores of 3.3910 \pm 1.34747 indicate that the respondents agreed moderately that quality of interaction between bank staff and customers affect brands on Facebook that directly influence purchase decision in banks. 
Table 3 Facebook as a Dimension of Social Media Marketing

\begin{tabular}{|l|l|l|c|}
\hline & \multicolumn{1}{|c|}{ Question Items } & Mean & Standard Deviation \\
\hline 1 & $\begin{array}{l}\text { To what extent does Facebook offer veritable } \\
\text { opportunities to optimize social media marketing } \\
\text { efficiency (conversion rate, web traffic, and customer } \\
\text { engagement) in your bank? }\end{array}$ & 3.5188 & 1.16516 \\
\hline 2 & $\begin{array}{l}\text { To what extent does the quality of interaction between } \\
\text { your staff and customers affect brands on Facebook } \\
\text { that directly influence purchase decision in your bank? }\end{array}$ & 3.3910 & 1.34747 \\
\hline 3 & $\begin{array}{l}\text { To what extent does passing marketing information on } \\
\text { Facebook lead to the achievement of the expected } \\
\text { marketing results in your bank? }\end{array}$ & 3.6992 & 1.10086 \\
\hline 4 & $\begin{array}{l}\text { To what extent does your bank give rooms for staff to } \\
\text { suggest new ways or approach for giving potential and } \\
\text { actual customers satisfaction information on Facebook? }\end{array}$ & 3.7820 & 1.06841 \\
\hline 5 & $\begin{array}{l}\text { To what extent does the attraction of customers on } \\
\text { Facebook become everybody's business in your bank? }\end{array}$ & 3.6316 & 1.06936 \\
\hline
\end{tabular}

Source: Survey Data, 2019, and IBM SPSS Statistics 22 Window Output

Keys: VLGE = very large extent, $\mathrm{LGE}=$ large extent, $\mathrm{MDE}=$ moderate extent, $\mathrm{LWE}=$ low extent, VLWE: very low extent, S.D: standard deviation.

\subsubsection{Twitter as a Dimension of Social Media Marketing}

Table 4 Twitter as a Dimension of Social Media Marketing

\begin{tabular}{|l|l|c|c|}
\hline No & \multicolumn{1}{|c|}{ Question Items } & Mean & Standard Deviation \\
\hline 1 & $\begin{array}{l}\text { To what extent does the quality of interaction between } \\
\text { your staff and customers affect brands in Twitter that } \\
\text { directly influence purchase decision? }\end{array}$ & 3.7895 & 1.13520 \\
\hline 2 & $\begin{array}{l}\text { To what extent does your bank's Twitter offer veritable } \\
\text { opportunities to optimize bank's efficiency (conversion } \\
\text { rate, web traffic, customer engagement) }\end{array}$ & 3.4962 & 1.14564 \\
\hline 3 & $\begin{array}{l}\text { To what extent are there opportunities to develop the } \\
\text { staff on the use of Twitter to attract customers to your } \\
\text { bank? }\end{array}$ & $\begin{array}{l}\text { To what extent does your bank provide staff with } \\
\text { Twitter-based facilities to encourage marketing } \\
\text { activities? }\end{array}$ & 3.6015 \\
\hline 5 & $\begin{array}{l}\text { To what extent does your bank usually optimize } \\
\text { customer attraction through the use of Twitter? }\end{array}$ & 3.4211 & 1.36507 \\
\hline
\end{tabular}

Source: Survey Data, 2019, and IBM SPSS Statistics 22 Window Output

Keys: VLGE = very large extent, $\mathrm{LGE}=$ large extent, $\mathrm{MDE}=$ moderate extent, $\mathrm{LWE}=$ low extent,

VLWE: very low extent, S.D: standard deviation. 
Table 4 shows that the mean and standard deviation scores of $3.7895 \pm 1.13520$ as indicated by the respondents implying that to a large extent the quality of interaction between bank staff and customers affect brands in Twitter that directly influences the purchase decision. Also, the mean and standard deviation scores of 3.6015 \pm 1.16085 imply that the respondents were favorable to the large extent option that banks provide staff with Twitter-based facilities to encourage marketing activities. This kind of disposition is in support of the fact that banks are extensively using Twitter to attract customers for patronage. The data revealed that the mean and standard deviation scores of $3.4962 \pm 1.14564$ as indicated by the respondents confirm moderately that bank's Twitter offers veritable opportunities to optimize bank's efficiency (conversion rate, web traffic, customer engagement). The mean and standard deviation scores of 3.4211 \pm 1.23221 depict moderate agreement by the respondents regarding the extent to which banks usually optimize customer attraction through the use of Twitter. The respondents were inclined to the moderate extent option as revealed in the mean and standard deviation scores of $3.3008 \pm 1.36507$ indicating that the presence of opportunities to develop the staff on the use of Twitter to attract customers to banks is of moderate use.

\subsubsection{LinkedIn as a Dimension of Social Media Marketing}

Table 5 LinkedIn as a Dimension of Social Media Marketing

\begin{tabular}{|c|l|c|c|}
\hline No & \multicolumn{1}{|c|}{ Question Items } & Mean & Standard Deviation \\
\hline 1 & $\begin{array}{l}\text { To what extent does your bank provide LinkedIn } \\
\text { facilities for engaging in marketing activities that } \\
\text { satisfy your customers? }\end{array}$ & $\begin{array}{l}\text { T.7970 } \\
\text { for onhline marketing activities that give profits to your } \\
\text { organization? }\end{array}$ & 2.2782 \\
\hline 3 & $\begin{array}{l}\text { To what extent does your bank recognize that LinkedIn } \\
\text { provides the customer with numerous product/service } \\
\text { options? }\end{array}$ & 3.3985 \\
\hline 4 & $\begin{array}{l}\text { To what extent does the quality of interaction between } \\
\text { your staff and customers affect your brands in LinkedIn } \\
\text { that directly influence purchase decision in the bank? }\end{array}$ & 3.6917 & 1.24531 \\
\hline 5 & $\begin{array}{l}\text { To what extent does your bank's LinkedIn offer } \\
\text { veritable opportunities to optimize bank's efficiency } \\
\text { (conversion rate, web traffic, and customer } \\
\text { engagement) }\end{array}$ & 3.2030 \\
\hline
\end{tabular}

Source: Survey Data, 2019, and IBM SPSS Statistics 22 Window Output

Keys: VLGE = very large extent, $\mathrm{LGE}=$ large extent, $\mathrm{MDE}=$ moderate extent, $\mathrm{LWE}=$ low extent,

VLWE: very low extent, S.D: standard deviation.

Table 5 revealed the mean and standard deviation scores of $3.7970 \pm 1.05715$ indicating that to a large extent banks provide LinkedIn facilities for engaging in marketing activities that satisfy their customers. Also, the mean and standard deviation scores of 3.6917 \pm 1.10220 signpost the fact that to a large extent the quality of interaction between bank staff and customers affect the brands in LinkedIn that directly influence purchase decision in the bank. 
The data as indicated by the respondents have revealed the mean and standard deviation scores of $2.2782 \pm 1.24531$ implying that to a low extent banks offer LinkedIn facilities for online marketing activities that give profits to their organizations. Also, the mean and standard deviation scores of 3.3985 \pm 1.31966 indicate moderate extent banks recognize that LinkedIn provides the customers with numerous products/services. Table 5 shows that the mean and standard deviation scores of 3.2030 \pm 1.22326 indicating that to a moderate extent the bank's LinkedIn offers veritable opportunities to optimize bank's efficiency (conversion rate, web traffic, and customer engagement.

\subsubsection{Conversion Rate as a Measure of Organisational Efficiency of Banks}

Table 6 shows the descriptive statistical results on conversion rate which is measured with five question items on the 5-point scale. The response distribution as shown by the results is indicative that the conversion rate will enhance organizational efficiency of banks.

Table 6 Conversion Rate as a Measure of Organisational Efficiency of Banks

\begin{tabular}{|l|l|c|c|}
\hline No & \multicolumn{1}{|c|}{ Question Items } & Mean & Standard Deviation \\
\hline 1 & $\begin{array}{l}\text { To what extent does social media marketing boost rate } \\
\text { conversion of your bank? }\end{array}$ & 3.7744 & 1.01217 \\
\hline 2 & $\begin{array}{l}\text { To what extent are you involved in important marketing } \\
\text { activities that improve the conversion rate of your } \\
\text { bank? }\end{array}$ & 3.9624 & 1.85213 \\
\hline 3 & $\begin{array}{l}\text { To what extent does your bank consider the opinion of } \\
\text { others before making an important decision that affects } \\
\text { the conversion rate of the bank? }\end{array}$ & 3.8195 & 1.16667 \\
\hline 4 & $\begin{array}{l}\text { To what extent do senior marketing staff discuss issues } \\
\text { concerning the increase of conversion rate in your bank }\end{array}$ & 3.9098 & 0.90837 \\
\hline 5 & $\begin{array}{l}\text { To what extent is conversion rate often used as a key } \\
\text { performance index (KPI) to review the effectiveness } \\
\text { and efficiency in your bank? }\end{array}$ & 3.6992 & 1.04436 \\
\hline
\end{tabular}

Source: Survey Data, 2019, and IBM SPSS Statistics 22 Window Output

Keys: VLGE = very large extent, $\mathrm{LGE}=$ large extent, $\mathrm{MDE}=$ moderate extent, $\mathrm{LWE}=$ low extent, VLWE: very low extent, S.D: standard deviation.

Table 6 shows the mean and standard deviation scores of $3.9624 \pm 1.85213$ indicating that the consensus opinion of the respondent is that to a large extent bank staff are involved in important marketing activities that improve the conversion rate of their banks. Also, the mean and standard deviation scores of $3.9098 \pm 0.90837$ imply that to a large extent senior marketing staff discusses issues concerning the increase of conversion rate in banks. The statistical result of $3.8195 \pm 1.16667$ (mean and standard deviation scores) show that to a large extent banks consider the opinion of others before making an important decision that affects the conversion rate of their organization. Table 6 also reveals the mean and standard deviation scores of $3.7744 \pm 1.01217$ implying that the respondents agreed that to a large extent social media marketing is boosted by rate conversion of banks. Finally, the mean and standard deviation scores of $3.6992 \pm 1.04436$ show that the respondents agreed that to a large extent conversion rate is often used as a key performance index (KPI) to review the effectiveness and efficiency of banks. 


\subsection{Validity and Reliability}

Data refinement is practically done to ensure rationality in the study and the need to show the reliability of the instrument in terms of the measurement of the concepts and constructs investigated in the study. To achieve this, reliability has been ascertained relying on Cronbach alpha using the Nunnally \& Bernstein's (1994) threshold, alpha values for the examined constructs and items are as follows:

Table 7 Test of Reliability

\begin{tabular}{|l|c|c|}
\hline Construct & No of items & Alpha $(\alpha)$ \\
\hline Blog & 5 & 0.861 \\
\hline Facebook & 5 & 0.771 \\
\hline Twitter & 5 & 0.857 \\
\hline LinkedIn & 5 & 0.740 \\
\hline Conversion rate & 5 & 0.722 \\
\hline Web traffic & 5 & 0.877 \\
\hline Customer engagement & 5 & 0.796 \\
\hline Trust & 5 & 0.790 \\
\hline Total & & 6.414 \\
\hline Mean Reliability & $6.414 \div 8$ & 0.80175 \\
\hline
\end{tabular}

Source: Survey Data, 2019, and IBM SPSS Statistics 22 Window Output

From the alpha outcomes in Table 7, the instrument is a dependable one and identified with the topic of the study. The information gathering instrument was tried for unwavering quality utilizing Cronbach's Alpha is within the acknowledged scope of 0.70 or more as the overall reliability test of the instrument is 0.80175 . Validity test was additionally done, utilizing specialists proficient in the subject matter under investigation, experts and supervisors' endorsement to determine that the instruments were significant and measured what they were designed to measure. The predictors and the criterion variables were found to be dependable as a construct have alpha values above the Nunnally threshold of 0.7 (Akujuru \& Enyioko, 2018).

\subsection{Research Analysis}

The study has sought to determine the extent of the relationship between social media marketing and conversion rate of banks. As a result, five research questions and thirteen hypotheses were raised to that effect. The next step of the study analysis tested the outcomes of the examined dimensions and measures of the variables in terms of relationship. Therefore, this section tested and interpreted the hypotheses formulated in this study. The data in Table 1 have been used to test hypotheses one, two, three and four in this study 
JEMA: Jurnal Ilmiah Bidang Akuntansi dan Manajemen, Vol. 16 No. 1 (2019)

http://riset.unisma.ac.id/index.php/jema (e-ISSN : 2597-4071)

Table 8 Results of Social Media Marketing (SMM) and Conversion Rate (CR)

\begin{tabular}{|l|c|c|c|c|c|l|}
\hline \multirow{2}{*}{ Variable } & \multicolumn{2}{|c|}{ Unstandardized Coeff. } & $\begin{array}{c}\text { Standardized } \\
\text { Coef. }\end{array}$ & \multirow{2}{*}{ t } & Sig. & Decision \\
\cline { 2 - 4 } & B & Std Error & Beta & & & \\
\hline (Constant) & 2.127 & 0.185 & & 11.495 & 0.000 & \\
\hline Blog $\left(\mathrm{H}_{1}\right)$ & 0.030 & 0.081 & 0.049 & 0.373 & 0.710 & Insignificant \\
\hline Facebook $\left(\mathrm{H}_{2}\right)$ & 0.224 & 0.063 & 0.431 & 3.570 & 0.001 & Significant \\
\hline Twitter $\left(\mathrm{H}_{3}\right)$ & 0.220 & 0.084 & 0.294 & 2.621 & 0.010 & Significant \\
\hline LinkedIn $\left(\mathrm{H}_{4}\right)$ & 0.028 & 0.080 & 0.033 & 0.349 & 0.728 & Insignificant \\
\hline
\end{tabular}

Source: Survey Data, 2019, and IBM SPSS Statistics 22 Window Output

Therefore the multiple regression equation models based on table above can be described as ;

$$
\begin{aligned}
& \mathrm{Y}_{1}=\mathrm{b}_{\mathrm{o}}+\mathrm{b}_{1} \mathrm{x}_{1}+\mathrm{b}_{2} \mathrm{x}_{2}+\mathrm{b}_{3} \mathrm{x}_{3}+\mathrm{b}_{4} \mathrm{X}_{4}+\mathrm{e} \\
& \text {-(1) \{for testing } \mathrm{H}_{1}, \mathrm{H}_{2}, \mathrm{H}_{3}, \mathrm{H}_{4} \text { \} } \\
& \mathrm{Y}_{1}(\text { Conversion rate })=2.127+0.030 \mathrm{Blog}+0.224 \mathrm{Face}+0.220 \mathrm{Twit}+0.028 \mathrm{Link}+\mathrm{e} \\
& \mathrm{t} \quad=\quad(0.373) \quad(3.570) \quad(2.621)
\end{aligned}
$$

Table of Results of Social Media Marketing (SMM) and Conversion Rate above also shows the results of the test of hypothesized statements $-\mathrm{H}_{1}, \mathrm{H}_{2}, \mathrm{H}_{3}$, and $\mathrm{H}_{4}$. The result of hypothesis 1 tested, show positive and insignificant effect of blog on conversion rate with t-value outcome of 0.374 with p-value (sig.) $0.710>0.05$, meaning that blog has a positive effect which is not significant on conversion rate, indicating that hypothesis $1\left(\mathrm{H}_{1}\right)$ has been rejected which means "Blog has no significant effect on conversion rate of banks". The result of hypothesis $2\left(\mathrm{H}_{2}\right)$ revealed a strong positive and significant effect of Facebook on conversion rate with $t$ - value outcome of $t=3.570$ with the p-value (sig.) $0.001<0.05$. By this result, it can be concluded that the hypothesis $2\left(\mathrm{H}_{2}\right)$ has been accepted which means "Facebook has a significant effect on the conversion rate of banks". With respect to hypothesis $3\left(\mathrm{H}_{3}\right)$, the result in Table 1 revealed strong positive and significant effect of Twitter on conversion rate with t-value outcome of 2.621 with p-value (sig.) $0.010<0.05$, therefore, the hypothesis $3\left(\mathrm{H}_{3}\right)$ has been accepted which means "Twitter has a significant effect on the conversion rate of banks". In the case of LinkedIn and conversion rate which is hypothesis 4 $\left(\mathrm{H}_{4}\right)$, the result of the hypothesis $4\left(\mathrm{H}_{4}\right)$ tested, show positive and insignificant effect of LinkedIn on conversion rate with $t$ - value outcome of 0.349 with p-value (sig.) $0.728>0.05$, denoting that LinkedIn has a positive effect which is not significant on conversion rate. Therefore, the hypothesis $4\left(\mathrm{H}_{4}\right)$ has been rejected, "LinkedIn has positive but no significant effect on conversion rate of banks". From the inferential statistical analysis so far, it can be stated that:

a. Blog as a dimension of social media marketing has a positive and insignificant effect on conversion rate which is a measure of the conversion rate of banks. This simply means that blog as a marketing instrument influences conversion rate positively, but the effect is not significant as one of the key performance indicators for measuring efficiency in social media marketing.

b. Facebook as a dimension of social media marketing has a strong positive and significant effect on conversion rate. This simply means that Facebook as a social media marketing strategy positively influences conversion rate which is a measure of the conversion rate of banks and it contributes to the success of marketing performance.

c. Twitter as a dimension of social media marketing has a strong positive and significant effect on conversion rate as a measure of the conversion rate of banks. This simply means that Twitter 
contributes positively to conversion rate and it is a measure of the conversion rate of banks in social media marketing.

d. LinkedIn as a dimension of social media marketing has a positive and insignificant effect on conversion rate which is a measure of the conversion rate of banks. This simply means that LinkedIn as a marketing instrument influences conversion rate positively but the effect is not significant as one of the key performance indicators for measuring efficiency in social media marketing.

Table 9 Summary of the Results on Test of the Research Hypotheses

\begin{tabular}{|l|c|c|c|c|}
\hline \multicolumn{1}{|c|}{ Research Hypotheses } & t- value & Prob. Value (Sig.) & Result & Decision \\
\hline $\begin{array}{l}\text { A blog has significant } \\
\text { effect on the conversion } \\
\text { rate of banks }\left(\mathrm{H}_{1}\right)\end{array}$ & 0.37 & 0.710 & Positive, Insignificant effect & Reject \\
\hline $\begin{array}{l}\text { Facebook has a } \\
\text { significant effect on the } \\
\text { conversion rate of banks } \\
\left(\mathrm{H}_{2}\right)\end{array}$ & 3.57 & 0.001 & Positive, Significant effect & Accept \\
\hline $\begin{array}{l}\text { Twitter has a significant } \\
\text { effect conversion rate of } \\
\text { banks (H })\end{array}$ & 2.62 & 0.010 & Positive, Significant effect & Accept \\
\hline $\begin{array}{l}\text { LinkedIn has a } \\
\text { significant effect on the } \\
\text { conversion rate of banks } \\
\left(\mathrm{H}_{4}\right)\end{array}$ & 0.35 & 0.728 & Positive, Insignificant effect & Reject \\
\hline
\end{tabular}

Source: Survey Data, 2019, and IBM SPSS Statistics 22 Window Output

One of the study's regression assumptions is that the residuals (prediction errors) are normally distributed. The histogram in picture 2 reveals that this holds for the results of the data as the residuals for testing the effect of social media marketing conversion rate of banks were normally distributed. 


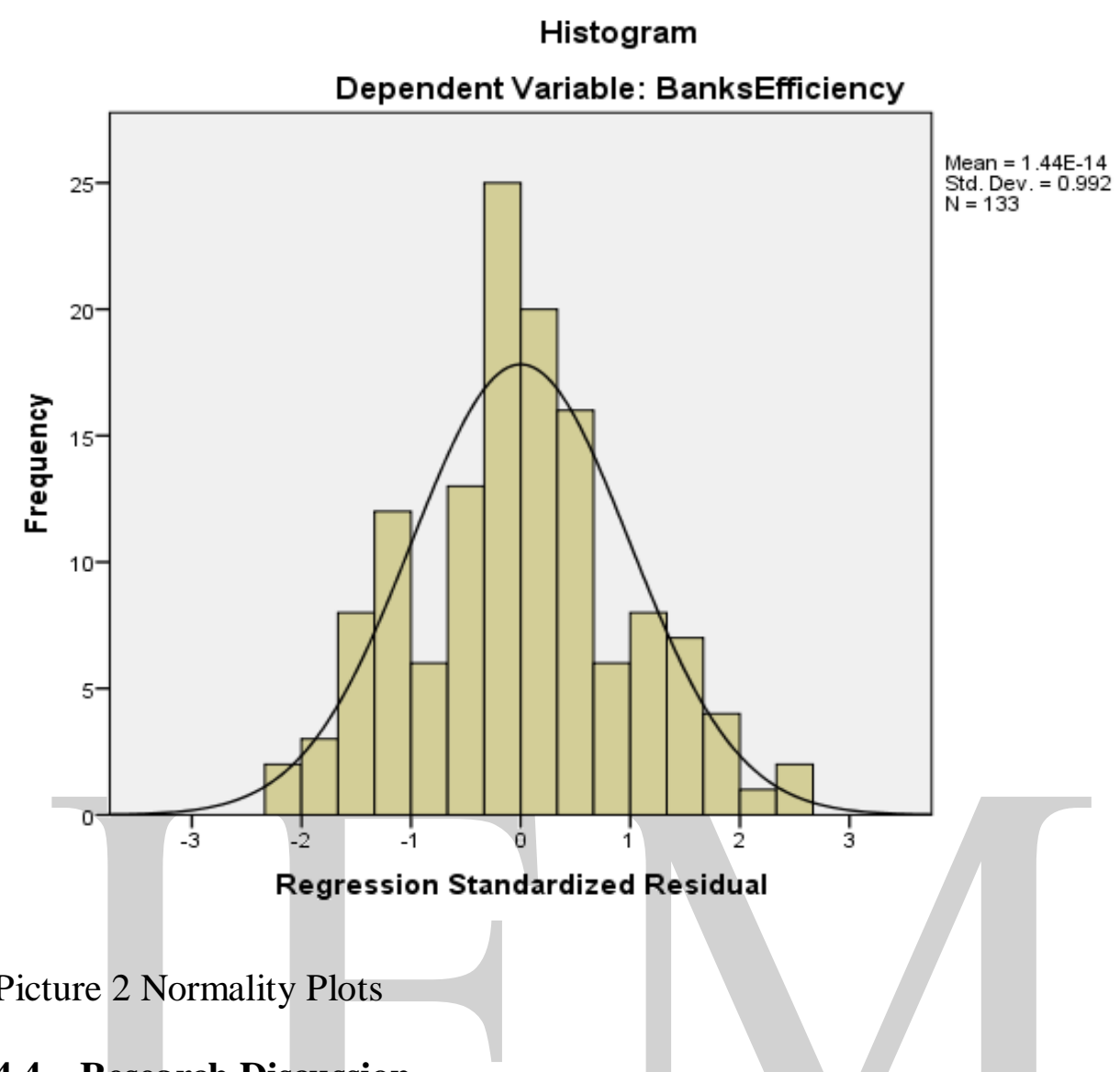

\subsection{Research Discussion}

The findings of this study were drawn from the analyses of the results in the previous chapter. In this chapter, the study discusses the findings to conclude appropriately. However, the study interprets and discusses the findings in five compartments according to the basic dimensions of the study's predictor variables against the criterion variables and the moderator variable.

\subsubsection{Effect of Blog on The Conversion Rate of Banks}

The findings linked to the effect of the blog on the conversion rate of banks revealed that banks use the blog to conduct their marketing activities and that this elicits conversion rate of banks. A critical appraisal of the finding reveals that the blog has a positive but insignificant effect on conversion rate. In all, the blog has a strong positive and significant effect on the conversion rate of banks. The full import of this finding is that banks use blog software that provides a variety of social features, including comments, blogrolls, trackbacks, and subscriptions that make it possible for the conversion rate of the banks to be improved (Bernoff, 2009). In asserting this position, Agnihotri, Dingus, Hu \& Krush (2016) insist that blog now largely falls under the remit of internal marketing so there is little disbelief that the intended audience and overall objectives differ little from traditional marketing. The study also found that banks introduce any products or services of interest in the blog and customers talk good about banks' willingness to use the best blog instruments/facilities for their marketing activities geared at engaging customers to patronize their products and services. The study, therefore, concludes that: As banks use blogs to create awareness about their products and services on the internet their conversion rates may be insignificant but are positively boosted. 


\subsubsection{Effect of Facebook on The Conversion Rate of Banks}

The study found a positive and significant effect of Facebook on the conversion rate of banks and this points to the fact that Facebook is one of the biggest channels in the social media to enhance conversion rates of banks that are digitally vibrant. A diagnostic examination of the findings reveals that the effect of Facebook on conversion rate is positive and significant. To support this assertion Nwokah \& Gladson-Nwokah (2017) contend that Facebook as a dimension for social network site is one of the best platforms to mobilize an online community to banks brand and products. Nwokah \& Aeenee (2017) also found that a strong and significant relationship exists between Facebook as a dimension of social networks and customer engagement as a dimension of customer acquisitions

Facebook is considered as the most popular and widely used network among other social media networks. In America, 30\% of perusing time is represented by Facebook while it is only 11\% for Good and YouTube together. Its massive number of users encourage business firms to use it to reach their target customers. Thus $92 \%$ of companies worldwide currently use Facebook as a marketing tool (Nwokah, 2018). Therefore, having a presence on Facebook makes brands discoverable and connected (Pinto \& Yagnik, 2017). This study agrees with the above submissions as it is revealed that banks' use of Facebook for marketing has become massive and resourceful. The study, therefore, concludes that: As banks customize the use of Facebook to publicize their products and services digitally, their conversion rates are boosted in a significant and positive manner.

\subsubsection{Effect of Twitter on The Conversion Rate of Banks}

The result about the effect of Twitter on a conversion rate of banks points to the fact that Twitter provides prospects and customers with a medium of getting information about the bank's products and services. A critical evaluation of the finding reveals that the effect of Twitter on conversion rate is positive and significant. In line with this, Nwokah \& Gladson-Nwokah (2015) insist that there is a very strong and significant relationship between Twitter as a dimension of social networks and customer engagement as a dimension of customer acquisitions. This study has revealed positive indications which are significant between Twitter and conversion rate of banks (conversion rate, web traffic, and customer engagement). Corroborating on this Nwokah \& Aeenee (2017) contend that Twitter plays important role in social media marketing as it significantly affects business models online. Nwokah \& Aeenee (2017) conclude that Twitter is a channel that encourages a product in actual transactions and attracts customers for the achievement of marketing objectives

This study is of the view that engaging in social media channels with a particular interest in twitting is key to extending the banks' reach. This is because it is important for organizations to be able to reach their customers through social media activities as demand for this is continually rising. Enyioko (2018) assert that twitting enables companies to manage social media in a highly regulated environment while enabling consumers to reap the full benefits of being linked to the bank on web traffic that customers can access.

\subsubsection{Effect of LinkedIn on The Conversion Rate of Banks}

The finding of the study relating to the effect of LinkedIn on the conversion rate of banks is positive but insignificantly inclined. Critical examination of the findings reveals that LinkedIn has a positive but insignificant effect on conversion rate. Nwokah (2018) portrays the vital employment of LinkedIn in building connections, understanding prospects, handpicking particular prospects, pulling in prospects to a specific brand, and tuning in to customers. The banking sector, as 
represented by the surveyed banks, appears far more focused on leveraging LinkedIn as a tool than the other sectors. As the research on the effect of the LinkedIn on the conversion rate of banks shows, banks are including visual reminders of conversion rate, web traffic intensity and customer engagement outcomes on their websites more often. The study, therefore, concludes that: As banks use of LinkedIn to advertise their products and services digitally, their conversion rates are enhanced positively, but the output is not significant.

Social media marketing is a recent phenomenon; it has proven to be a very effective and efficient tool and should be viewed as a major actor in creating awareness. Bank managers should use a blog to their advantage by encouraging bank staff and not just the marketing department to participate in social media marketing which in turn covers more ground for the enhancement of conversion rate, web traffic and customer engagement leading to the conversion rate of banks.Twitter can also be a good platform for building goodwill and improving corporate image, the study recommends that banks engage consumers in friendly competitions, hosted on their Twitter pages and also take part in self-promotion by uploading photos of events i.e., charity events, products, and services. Banks should update their knowledge with respect to social media marketing and the opportunities provided by digital measurement solutions so as to be able to assess the effectiveness and efficiency of social media marketing. Naturally, the social media platforms should be linked with the firm's customer relationship management system so as to form a complete picture of organizational efficiency of banks.

\section{RESEARCH CONCLUSION AND LIMITATION}

\subsection{Conclusion}

Social media marketing is a powerful tool for engaging new audiences, building a brand identity, and strengthening customer contacts. It can impact on the growth of banks and other businesses when developed with care, your content will transform your marketing team into a customer acquisition engine. Based on the findings of the study, the conclusion of the study is as banks use blogs to create awareness about their products and services on the internet their conversion rates may be insignificant but is positively boosted. As banks customize the use of Facebook to publicize their products and services digitally, their conversion rates are boosted in a significant and positive manner. As banks engage in twitting to create awareness and persuade customers to purchase their products and services their conversion rates are positively and significantly boosted. This means that Twitter is strong in producing conversion rate which is a measure of the conversion rate of banks. As banks use LinkedIn to advertise their products and services digitally, their conversion rates are enhanced positively, but the output is not significant. Therefore, bank managers should use a blog to their advantage by encouraging bank staff and not just the marketing department to participate in social media marketing which in turn covers more ground for the enhancement of conversion rate, web traffic and customer engagement leading to the conversion rate of banks. Twitter can also be a good platform for building goodwill and improving corporate image, the study recommends that banks engage consumers in friendly competitions, hosted on their Twitter pages and also take part in self-promotion by uploading photos of events i.e., charity events, products, and services. Also, banks should update their knowledge with respect to social media marketing and the opportunities provided by digital measurement solutions so as to be able to assess the effectiveness and efficiency of social media marketing. Naturally, the social media platforms should be linked with the firm's customer relationship management system so as to form a complete picture of organizational efficiency of banks. 


\subsection{Limitation}

Like any other academic research, this work was without limitations. Time and cost posed many challenges as well as hoarding of data by the respondents. This work considered the entire banks in Nigeria, but the limitations imposed by time and cost influenced the researcher's decision to concentrate on banks in Nigeria. The researcher also encountered certain difficulties in connection with data collection. The nature of this study required the researcher to collect data on the internet from the banks in Nigeria. Finally, it was difficult to convert the research and analysis of social media marketing and organizational efficiency of banks into a problem formulation that allowed for a critical investigation including enough theories to explore and concretize same, and this limited the depth of the study. In spite of these delimitations, the study domain holds sufficient academic curiosity for thorough investigations and perusals.

\section{REFERENCES}

Agnihotri, R., Dingus, R., Hu, M. Y., \& Krush, M. T. (2016). Social media: Influencing Customer Satisfaction in B2B sales. Industrial Marketing Management, 53, 172-180. https://doi.org/10.1016/j.indmarman.2015.09.003.

Agostino, D., \& Sidorova, Y. (2016). A performance measurement system to quantify the contribution of social media: new requirements for metrics and methods. Measuring Business Excellence, 20(2), 38-51. https://doi:10.1108/MBE-05-2015-0030.

Akujuru, C. A., \& Enyioko, N. C. (2018). Social Science Research: Methodology and conceptual Perspectives. Beau Bassin: Lambert Academic Publishing.

Altman, I., \& Taylor, D,A. (1973). Social Penetration: The Development of Interpersonal Relationship. New York: Holt, Rinehart and Winston.

Altman, I., Vinsel, A., \& Brown, B.B. (1981). Dialectic conceptions in social psychology: An application to social penetration and privacy regulation. Advances in experimental social psychology, 14, 107-160. https://doi.org/10.1016/S0065-2601(08)60371-8.

Ashley, C., \& Tuten, T. (2015). Creative strategies in social media marketing: An exploratory study of branded social content and consumer engagement. Psychology \& Marketing, 32(1), 15-27. https://doi:10.1002/Mar.20761.

Basak, E., \& Calisir, F. (2014). Uses and Gratifications of Linkedln: An Exploratory Study. Lecture Notes in Engineering and Computer Science, 2212(1), 1153-1156.

Batra, R., \& Keller, K. L. (2016). Integrating Marketing Communications: New findings, New Lessons, and New Ideas. Journal of Marketing, 80(6), 122-145. https://doi.org/10.1509/jm.15.0419.

Bax, S., Meyer, K., \& Wilkins, N. (2013). Cambridge marketing handbook: Digital, Cambridge Marketing College. London: Kogan Page Limited

Bernoff, J. (2009). Blogs, Marketing and Trust. Marketing News, issue. Retrieved from http://mpdev.marketingpower.com/ResourceLibrary/Publications/MarketingNews/2009/43/2 /Feb_15_ViewPoint_Bernoff.pdf.

Cavazza, F. (2018). The social media landscape 2018. Retrieved from www.fredcavazza.net. 
Chaffey, D., \& Smith, P. R. (2013). E-marketing excellence: Planning and Optimizing Your Digital Marketing $4^{\text {th }} e d$. London: Taylor \& Francis.

Charlesworth, A. (2014). Digital marketing: A Practical Approach ( $2^{\text {nd }}$ ed.). New Jersey: Routledge.

Conklin, J. (2015). Leverage LinkedIn. Quality Progress, 48(1), 50.

Dedu, V., \& Niţescu, D. C. (2014). Banking Relationship Management - A New Paradigm?. Theoretical and Applied Economics XXI, 4(593), 7-22.

Elena, C. A. (2016). Social media-A strategy in developing customer relationship management. Procedia Economics and Finance, 39, 785-790.

Elliot, N. (2015). How does your brand stack up on Facebook, Twitter and Instagram? Retrieved from http://blogs.forrester.com/nate.

Fisher, T. (2009). ROI in social media: A look at the arguments. Journal of database marketing \& customer strategy management, 16(3), 189-195. https://doi.org/10.1057/dbm.2009.16.

Florenthal, B. (2015). Applying uses and gratifications theory to students' LinkedIn usage. Young Consumers, 16(1), 17-35. https://doi.org/10.1108/YC-12-2013-00416.

Gaudin, S. (2010). Facebook slapped with class-action privacy lawsuit. Retrieved from goo.gl/7MLycR.

Guay, M. (2015). The 20 best online survey builder tools, Zapier. Retrieved from www.zapier.com/blog/best-survey-apps/.

Halim, R. E. (2010). Marketing productivity and profitability of Indonesian public listed manufacturing firms. In: Benchmarking: An International Journal, 6(17), 842-857. https://doi.org/10.110814635771011089755.

Hoban, P. R., \& Bucklin, R. E. (2015). Effects of internet display advertising in the purchase funnel: Model-based insights from a randomized field experiment. Journal of Marketing Research, 52(June), 375-393. https://doi.org/10.1509/jmr.13.0277.

Järvinen, J., \& Karjaluoto, H. (2015). The use of web analytics for digital marketing performance measurement. Industrial Marketing Management, 50, 117-127. https://doi.org/10.1007/978-3319-10912-1_157.

Kanovska, L., \& Tomaskova, E. (2012). Inter-functional coordination at hi-tech firm. Engineering Economics, 23(1), 70-76, http://dx.doi.org/10.5755/j01.ee.23.1.1224.

Krejcie, R. V., \& Morgan, D. W. (1970). Determining Sample Size for Research Activities. Educational and Psychological Measurement, 30, 607-610. https://doi.org/10.1177/001316447003000308.

Kumar, A., \& Salo, J. (2018). Effects of link placements in email newsletters on their click-through rate. Journal of Marketing Communications, 50(October), 561-576. https://doi.org/10.1080/13527266.2016.1147485.

Lilien, G. L. (2016). The b2b knowledge gap. International Journal of Research in Marketing, 75(July), 196-210. https://doi.org/10.1016/j.ijresmar.2016.01.003. 
Ling-yee, L. (2011). Marketing metrics' usage: Its predictors and implications for customer relationship management. Industrial Marketing Management, 40(Business-to-Business $\begin{array}{llll}\text { Marketing in } \text { BRIC 139-148. } & \text { Countries), }\end{array}$ https://doi.org/10.1016/j.indmarman.2010.09.002.

McCann, M., \& Barlow, A. (2015). Use and measurement of social media for SMEs. Journal of Small Business and Enterprise Development, 22(2), 273-287. https://doi.org/10.1108/JSBED08-2012-0096.

Mehmet, M. I., \& Clarke, R. J. (2016). B2B social media semantics: Analysing multimodal online meanings in marketing conversations. Industrial Marketing Management, 54, 92-106. https://doi.org/10.1016/j.indmarman.201512.006.

Morgan, H. (2014). Don't believe these 8 job search myths. Retrieved from http://money.usnews.com/money/blogs/outside-voices-careers/2014/09/17/dont-believe-these8-job-search-myths.

Murdough, C. (2009). Social media measurement: It's not impossible. Journal of Interactive Advertising, 10(1), 94-99. https://doi.org/10.1080/15252019.2009.1072216.

NBS \& CBN Statistical Bulletins, (2016/2017). Data is supplied administratively by the Central Bank of Nigeria $(\mathrm{CBN})$ and verified and validated by the National Bureau of Statistics, Nigeria (NBS).

Nunnally, J. C., \& Bernstein, I. H. (1994). Psychometric theory (3rd ed.). New York: McGraw-Hill

Nwokah, N. G., \& Gladson-Nwokah, J. (2015). Impact of social network on customer acquisition in the banking industry in Nigeria. Information and Knowledge Management, 5(5) 150-163. Retrieved from www.iiste.org.

Nwokah, N. G., \& Aeenee, F. L. (2017). Social media marketing and business success of automobile dealers in Rivers State. American Journal of Industrial and Business Management, 7, 1298-1319.

Nwokah, N. G., \& Irimagha, B. B. (2017). E-Marketing Orientation and Social Media Implementation in the Banking Industry in Nigeria. iBusiness, 9(04), 111-133. https://doi.org/10.4236/ib.2017.94090.

Nwokah, N. G. (2018). From bricks and mortar to click and mortar marketing strategies. An Inaugural Lecture Series No. 59. Rivers State University, Port Harcourt.

Pinto, M. B., \& Yagnik, A. (2017). Fit for life: A content analysis of fitness tracker brands use of Facebook in social media marketing. Journal of Brand Management, 24(1), 49-67. https://doi.org/10.1057/s41262-016-0014-4.

Rapp, A., Beitelspacher, L. S., Grewal, D., \& Hughes, D. E. (2013). Understanding social media effects across seller, retailer, and consumer interactions. Journal of the Academy of Marketing Science, 41(5), 547-566. https://doi.org/10.1007/s11747-013-0326-9.

Ryan, D. (2014). Understanding Digital Marketing: Marketing Strategies for Engaging The Digital Generation ( $3^{\text {rd }}$.ed.). London: Kogan Page Ltd.

Sen, S. (2015). Six metrics every business should be tracking. Retrieved from http://blog.loginradius.com/metrics-every-businessshould-track. 
*) Newman C. Enyioko, Department of Marketing, Rivers State University, Port Harcourt, Nigeria (Email: newmanenyioko@yahoo.com)

**) Gabriel A. Okwandu, Department of Marketing, Rivers State University, Port Harcourt, Nigeria (Email: gokwandu@yahoo.com)

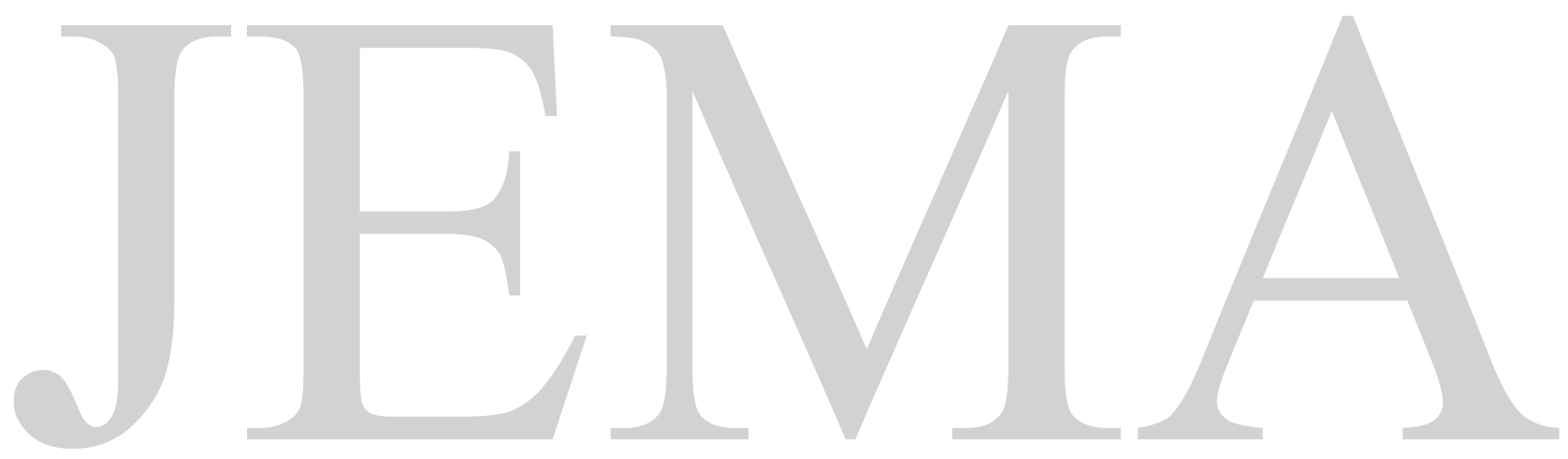

